\title{
Proving provenance? \\ Geographical Indications certification and its ambiguities
}

\author{
D S Gangjee
}

\section{Draft - please do not cite}

Please refer to the final version for citation purposes: DS Gangjee, 'Proving Provenance? Geographical Indications Certification and its Ambiguities' (2017) World Development (forthcoming)

\section{INTRODUCTION}

For foodstuffs and agricultural products, provenance matters like never before. While an individual's food consumption choices are a private matter, in the aggregate these choices have considerable social consequences, impacting on economic development, ecological sustainability, global transport systems and the relationship between urban and rural areas (Morgan, Marsden \& Murdoch, 2006). Geographical Indications (GI) protection systems are legal regimes which facilitate the signalling of this provenance in marketplaces. According to the World Intellectual Property Organization (WIPO), the "basic concept underlying GIs is simple, and familiar to any shopper who chooses Roquefort over 'blue' cheese or Darjeeling over 'black' tea... [these are] well-known examples of names associated throughout the world with products of a certain nature and quality, known for their geographical origin and for having characteristics linked to that origin" (WIPO, 2012, p. 8). Registration-based GI certification systems verify the content of these interdependent provenance and quality signals, as a prerequisite to formal legal recognition and protection. Yet what precisely does it mean for a regional speciality product to be legally certified as a GI? What formal guarantees and reassurances are provided by public authorities? And how effective is certification? Motivated by scholarship which has investigated the effectiveness of Fairtrade certification (Steering Committee, 2012; Beuchelt \& Zeller, 2011; Ruben \& Fort, 2012), this paper critically assesses the extent to which a product's link to a defined geographical region (provenance), associated quality attributes and adherence to traditional methods of production (authenticity) are verified by this public, as opposed to private, authentication process. 
A close study of GI registration systems is rewarding for primarily two reasons. First, certification verifies the existence of a particular type of link with the region of origin. According to Article 22.1 of TRIPS, GIs are "indications which identify a good as originating in the territory of a Member, or a region or locality in that territory, where a given quality, reputation or other characteristic of the good is essentially attributable to its geographical origin" (emphasis added). Certification ensures that only those products which satisfy such a formal legal definition ought to be recognised and protected. This reinforces the credibility of GIs as market signals and mitigates the effects of market failure arising out of imperfect information (Crespi \& Marette, 2003). Additionally, drawing on place-based theorising emphasising the notion of embeddedness, ${ }^{1}$ the verification of this close connection to a region is considered crucial for achieving endogenous development goals (FAO, 2008; Réviron, Thevenod-Mottet \& El Benni, 2009; Augustin-Jean, 2012). As Bowen (2010b, p. 210) explains: "Because GIs root production in particular places and protect the unique environmental and cultural resources that have developed over time in these places, scholars and development practitioners have framed them as a means of localizing production within the framework of globalization". Optimistic appraisals suggest that "GIs may be as close to a comprehensive, equitable and market-oriented rural development package as we have seen" (Giovannucci, Josling, Kerr, O'Connor \& Yeung, 2009, p. 5). Registration-based certification mechanisms require this localizing link to be explicitly articulated, which then forms the axis for territorial development strategies. A suitable "link with the geographical origin will constitute the essential point on which an application for registration of a product as a geographical indication will be based" (WIPO, 2003, p. 9). Therefore investigating the extent to which GI registration systems certify this close connection to place is worthwhile. ${ }^{2}$

The second reason relates to comparatively greater 'public' or state involvement in GI protection, which sets it apart as an unusual category of intellectual property (IP). While the preamble to TRIPS confirms that "intellectual property rights are private rights", by contrast GIs are characterised by their high degree of state or quasi-public involvement (OECD, 2000, p. 10; Marie-Vivien 2010; Biénabe, Jordaan \& Bramley, 2013). As we will see below, manifestations of this state involvement are evident in the formal examination and certification process conducted by public authorities, within the context of sui generis GI registration systems. ${ }^{3}$ In pursuing this line of enquiry, the analysis presented here draws primarily on the European Union's (EU) GI registration system as a model, since it is the most institutionally well-developed regime and an exemplar of prescriptive, sui generis protection in international debates (Gangjee, 2012a, pp. 201-202). If certification by public authorities is proving to be successful anywhere, it should be here. The analysis is supplemented by insights from emerging GI regimes from the global South, which suggests that the findings in this paper are more broadly relevant. 
Section 2 commences by describing the various ways in which there is state involvement in GI protection. The registration-based certification process is the defining framework for state involvement, enabling a catalogue of wider interventions by public authorities. It then considers the justifications - as identified by the Court of Justice of the European Union (CJEU) and the European Commission (EC) - for having such a certification system. These justifications relate to the official guarantee of provenance, quality and authenticity that benefits consumers. Section 3 then outlines the formal stages of the registration process and the details required by the product specification. Stated briefly, registration is designed to verify information relating to provenance, quality and potentially authenticity, which facilitates the signalling function of GIs. Section 4 then considers the operation of this regime in practice, drawing on recent empirically grounded reviews of the European GI system. The gaps and flexibilities identified during the certification process expose the limitations of attempts to guarantee origin, quality and authenticity by public authorities. For instance, there are formally recognised exceptions to the requirement that raw materials must be sourced from within the region of origin. If the raison d'être of GI protection is to guarantee geographical origin, to what extent can such exceptions be reconciled? Formal registration has inherent blind spots, which dilutes the nature of the certification guarantee. Therefore as opposed to relying on this systemic guarantee, Section 5 concludes by drawing attention to the recent interest in the design of individual product specifications and which is framed by insights from collective action theory. The participants involved in such drafting initiatives extend well beyond public authorities, to include NGOs/civil society organisations, networks of academic researchers and international organisations. This exposes the hybridity of influences that exist between state or market paradigms. The paper therefore concludes by identifying product specification design as a more promising site for interventions that would enable GIs to deliver on their developmental potential.

\section{GI CERTIFICATION - THE UNDERLYING ASSUMPTIONS}

\section{(a) Mapping state involvement}

As a legal regime which regulates the use and misuse of commercially valuable geographical brands in the marketplace, GI protection is often compared with trademark law (Gangjee, 2012a, pp. 291-294). Both regimes are considered by some to be functionally equivalent mechanisms to enhance informational efficiency. By granting exclusive rights to control the use of signs, these legal regimes facilitate uncluttered origin signalling in the marketplace (Teuber, 2011a). While Articles 22-24 of TRIPS establish minimum international standards of protection for GIs, the agreement does not specify the methods of implementation and various national approaches coexist ( $0^{\prime}$ Connor \& Co., 
2007). For instance, the US largely incorporates GI protection within trademark law, which establishes a system of private rights and proprietary interests in signs (USPTO; Evans, 2013). Therefore while these are not mutually exclusive categories, a division has emerged between those countries prioritising trademark law and those adopting sui generis registration systems. ${ }^{4}$ The very act of establishing a separate system to accommodate regional products indicates that GI regimes are expected to do different kinds of legal work. Three inter-related features account for this: (1) As TRIPS acknowledges, a GI identifies a product for which a causally demonstrable link to a specific region exists; (2) this in turn suggest a collective - as opposed to individual interest in the use of the sign by all legitimate producers within the region, since the product's reputation and associated know-how is generated by collective effort; (3) this collective interest provides the basis for greater state involvement, since both legal entitlements and legal obligations need to be defined, allocated and co-ordinated. ${ }^{5}$

However GIs regimes go further than trademark law. Whereas the latter is primarily concerned with preserving the coherence of the sign in the marketplace (for e.g. prohibiting third party uses likely to confuse consumers about commercial origin), for sui generis GI systems defining methods of production and facilitating supply chain coordination are additional important outcomes. As Bowen (2010b, p. 233) notes: "The [appellation d'origine contrôlée] system tries to ensure that French GI schemes, as a whole, protect the link to terroir and maintain the use of 'local, loyal, and constant' production practices". The thickness of this regulatory intervention can be traced to the historic significance of certain agricultural products for national economies, as illustrated by viticultural overproduction and its effect on the livelihoods of grape-growers in $19^{\text {th }}$ and $20^{\text {th }}$ century France (Warner, 1960). It is also attributable to the symbolic status of many regional products (e.g. Champagne) that operate as national champions contributing to collective identity formation projects (Guy, 2007; Gangjee, 2012b). State oversight is therefore associated with these public goods aspects.

Besides establishing a distinct legislative framework for GIs, public authorities are operationally involved with GI protection at a number of levels. At the initial stages, public sector research institutions or Ministries of Agriculture have taken the initiative in identifying products with GI potential, conducting surveys and compiling inventories of likely targets (for e.g. FAO, 2012; Soam, 2005; Bérard \& Marchenay, 2008, pp. 49-50). Governmental authorities also promote the availability of a distinct registration procedure for regional products and the enhanced protection that flows from it, through road shows and workshops targeted at producers or their representatives (Rangnekar, 2009 , p. 9). They may facilitate the application process, providing technical guidance on product specification drafting, assisting with bureaucratic formalities and providing financial subsidies to offset the costs of registration (Hartman, 2012, pp. 184-190). In the 
EU, a review of the GI system notes that there is "a high level of guidance and interaction" in eight member states, where "help is provided to applicants in completing the application in order to give them the best chance of success" (London Economics, 2008, p. 69). Unlike other forms of IP such as patents or trademarks, where applicants pay a fee, in most EU Members the costs of the registration procedure for GIs are borne by public authorities (European Commission, 2009b, Annex B). Moreover, public authorities have a role to play as mediators, intervening in conflicts between stakeholders during the product specification drafting process. Perceived as neutral arbiters, they can overcome collective action problems (for e.g. where there is a dispute over the method of production or raw materials), bridging the divides between different interest groups and helping to build relationships of trust between competitors (Rangnekar, 2004, p.3; Tregear, Arfini, Belletti \& Marescotti, 2007, p. 16). Yet there are limits to the desirability of intervention beyond a point. While "[l]inking people, building up a structured collective marketing strategy and monitoring a collective organisation are costly... a topdown approach is seldom a success because it may not take sufficiently into account operators' concerns and commercial risks. Regional authorities or NGOs may initiate a commercial project but they must let private operators establish and drive it because it is the latter which will have to take the commercial and investment risks" (Réviron, Thevenod-Mottet \& El Benni, 2009, p. 19). Another potential pitfall is the scope for corruption or collusion between government officials and local elites (Bowen, 2010b, p. 234).

Once registration takes place, there continues to be potential for state involvement. In several countries the state or its departments are the notional "owners" of any proprietary interests in GIs, with suitably qualified producers having the right to use them (Gangjee, 2007, p. 1256-1257; Marie-Vivien, 2010, p. 122). By way of an illustration, the Government of Mexico is the registered rights holder for the appellation Tequila under WIPO's Lisbon Agreement, which reflects its status under Mexican law. ${ }^{6}$ Once product specification criteria are established, the public sector may subsequently assist with capacity building, helping individual artisanal producers to make the necessary adjustments in meeting newly framed standards. This includes assistance with satisfying quality control (inspection) mechanisms, increasing the scale and regularity of production as well as identifying terms of payment favourable to smaller producers (Kop, Sautier \& Gerz, 2006, pp. 90-91). Governmental agencies also promote the registration scheme as a whole, while showcasing individual registered products within it (European Commission, 2011, pp. 11-12). Finally, in sui generis regimes, there is potential state involvement in policing the use of the registered GI at two levels: (i) "internally", to ensure that producers within the region comply with product specifications, in order to avoid free rider problems and the ensuing erosion of trust in these signs; and (ii) "externally", in the marketplace, where administrative agencies check for the misuse of 
registered GIs by third parties (European Commission, 2008, p. 12; London Economics, 2008, pp. 73-77). ${ }^{7}$

As this catalogue of interventions suggests, in sui generis systems the frame for much of this involvement is provided by the certification process. Public authorities initiate, facilitate and finally scrutinise GI applications to a far greater extent than is found in alternative approaches such as collective or certification trademarks. This has generated a comparison between "two archetypal categories: permissive systems and prescriptive systems" (Deppeler, Stamm \& Thévenod-Mottet, 2011, p. 2), leading to a debate over which approach is better (Giovannucci, Josling, Kerr, O'Connor \& Yeung, 2009, pp. 49-59; Hughes, 2009). This paper seeks to contribute to this debate by arguing that while prescriptive systems clearly do provide more meaningful guarantees when compared with permissive ones, they also have significant gaps and blind spots. The current overreliance on the sui generis system's ability to certify provenance and authenticity is therefore giving way to an interest in the individual product specification design.

\section{(b) Justifying GI certification under prescriptive systems}

The EU GI certification process, arguably the most prominent of the prescriptive systems, is justified in two complementary ways. First, at a normative level court decisions and legislation have endorsed the information efficiency foundations of certification. Second, once GIs are established as reliable market signals, the successful branding of origin and quality, coupled with the depth of prescriptive regulatory oversight, could facilitate a range of policy agendas relating to regional development strategies. Each justification requires further elaboration.

Neoclassical microeconomics characterises consumers as utility maximising agents attempting to make optimal choices. This rational decision making is premised on the availability of sufficient information in the marketplace. However several types of products including agricultural or prepared food products, wines, spirits and crafts can be characterised as either experience goods or credence goods, whose quality cannot be verified by consumers prior to purchase. In these situations, sellers possess more information about the products than buyers, whereupon information asymmetry arises. This informational imbalance could lead to familiar forms of market failure such as adverse selection and the ensuing "market for lemons" (Arrow, 1963; Akerlof, 1970). Reputation signals and the transfer of information relating to product attributes are ways in which informational efficiency can be restored. State intervention usually takes the form of establishing a legal regime which grants exclusive rights to control the use of a sign under which products are sold, thereby protecting this information transmission. 
Stated simply, marks can now be trusted. This not only reduces consumer search costs but also prevents undesirable free riding. Additionally, in the case of GIs, credible information is provided about provenance, quality attributes and modes of production. (Bramley, Biénabe \& Kirsten, 2009; Teuber, 2011a). In this context, certification can be viewed as a method to empower consumers by converting credence or experience attributes into quasi-search ones (Jahn, Schramm \& Spiller, 2005).

Echoes of this information efficiency explanation can be found within the justifications for GI protection articulated by the CJEU. The need for justification arose in the context of "free movement of goods" based legal challenges to the national GI protection regimes of individual EU Member States in the 1970s-1980s. The argument was that national GI protection regimes which granted exclusive rights over appellations of origin (for e.g. Rioja being reserved for use on wines not only sourced and produced but also bottled within designated regions) acted as an obstruction to trade within the EU's internal market. The Court confirmed that (a) these national GI regimes were a potential impediment to the free movement of goods but that (b) they could be justified as permitted exceptions, based on their certification or guarantee functions which benefitted consumers. One of the earliest decisions on this point, in a dispute involving restrictions on German wine labelling, established that the essential function of GIs is to convey certain kinds of useful information: "registered designations of origin... always describe at the least a product coming from a specific geographical area". Therefore the objectives of protecting such designations included "in particular the need to ensure not only that the interests of the producers concerned are safeguarded against unfair competition, but also that consumers are protected against information which may mislead them. These appellations only fulfil their specific purpose if the product which they describe does in fact possess qualities and characteristics which are due to the fact that it originated in a specific geographical area" (emphasis added) (Commission v. Germany [1975], para 7). The Court subsequently confirmed that "the specific function of a registered designation of origin is to guarantee that the product bearing it comes from a specified geographical area and displays certain particular characteristics" (Delhaize v. Promalvin [1992], para 17). It also acknowledged the value of the reputation signal for both consumers and producers: "Such names may nevertheless enjoy a high reputation amongst consumers and constitute for producers established in the places to which they refer an essential means of attracting custom. They are therefore entitled to protection" (Exportur v. LOR [1992], para 28). ${ }^{8}$ In the early 1990s, this information efficiency justification was incorporated into the harmonized regime for pan-European registration-based protection established under Council Regulation (EEC) No. 2081/92 on the Protection of Geographical Indications and Designations of Origin for Agricultural Products and Foodstuffs. ${ }^{9}$ This logic continued to be evident in its successors, Regulation 
510/2006 and presently Regulation (EU) No. 1151/2012 on Quality Schemes for Agricultural Products and Foodstuffs (see Recital 18 and Article 4(1)).

This foundation of informational efficiency supports an additional normative basis for GI protection. To the extent that certification is effective and subsequent provenance branding is successful, it facilitates broader rural development initiatives. As Recital 4 of Regulation 1151/2012 states: “Operating quality schemes for producers which reward them for their efforts to produce a diverse range of quality products can benefit the rural economy. This is particularly the case in less favoured areas". By providing market-based rewards for producers who invest in quality and maintain traditions, GIs are increasingly perceived as multifunctional policy tools producing a range of public goods (Deppeler, Stamm \& Thévenod-Mottet, 2011, p. 6). Marie-Vivien (2010, p.121; citing to Sylvander, B., Allaire, G., Bellotto et. al., 2006) identifies "multiple objectives behind the protection of GIs: first, protection of consumers against fraud; second, protection of the producer of the good; third, territorial, local, regional and rural development; and, fourth, conservation of the biological resources, biodiversity and cultural diversity". Within the European context, research confirms that on the demand side consumers are attracted to and value traditional regional products. ${ }^{10}$ This consumer demand sustains price premiums for certain classes of GI products. A recent meta-analysis of food valuation studies estimating price premiums for agricultural products differentiated by GIs concludes that the highest percentage premium is available in markets for products with short supply chains and relatively limited subsequent processing, whereas products with value-added characteristics and longer supply chains may benefit more from individual branding (Deselnicu, Costanigro, Souza-Monteiro \& McFadden, 2013). A comprehensive study conducted for the European Commission in 2012 estimates that the total value premium of GIs in the EU is €29.8 billion (Chever, Renault, Renault \& Romieu, 2012).

Having identified the possibility of market-based rewards - both in terms of improved access and higher prices - GIs become the operational framework for pursuing territorially-based development strategies (Belletti \& Marescotti, 2011a). A guide for producers identifies the potential for a "virtuous circle", where sufficient consumer demand leads to the drafting of a product specification that is respectful of traditional production methods, inclusive in its coverage of the supply chain and designed with the sustainability of local resources in mind. Successful marketing, supported by complementary public policy interventions, would direct economic returns back into the local community, be mindful of distributive concerns and result in a sustainable production model (Vandecandelaere, Arfini, Belletti \& Marescotti, 2009-10, pp. 3-7). Specific aspects include the formal recognition of labour intensive or artisanal production techniques that are differentiated from mass-produced alternatives, thereby stabilising employment in the region (De Roest \& Menghi, 2000; London Economics, 2008, pp. 232- 
243); designing institutions to equitably redistribute profits along the supply chain; or aiming for environmental benefits (Réviron, Thevenod-Mottet \& El Benni, 2009).

In conclusion, it can be seen that the registration-based certification process is the framework within which state intervention generally takes place. The decision to establish a prescriptive, sui generis GI regime is a manifestation of "law in development" - where law is seen as playing an instrumental role, by generating the institutional context or rules of the game for influencing conduct that favours specific development outcomes (Prado, 2010). A foundational assumption here is that GI certification by public authorities will successfully act as a credible signal in the marketplace. Registered GI status will convey to consumers the requisite attributes of origin, quality and authenticity, while the system as a whole is designed to effectively verify these attributes. This is further reflected in the formal criteria to be satisfied during the registration process.

\section{AN OVERVIEW OF THE CERTIFICATION PROCESS}

There are four GI-related registration systems in the EU, distinguished on the basis of subject matter: (i) wines; (ii) aromatized wines, (iii) spirits and (iv) agricultural products as well as food stuffs. ${ }^{11}$ Only the fourth will be considered here, since it covers the broadest range of products. While GI registration is voluntary, a number of legal advantages flow from registration. ${ }^{12}$ The Commission has therefore been actively encouraging registration across the EU Membership (Hartman, 2012). Regulation $1151 / 2012$ stipulates that a publicly accessible register be established in order to "provide information to consumers and to those involved in the trade" (Recital 26; see also Article 11). Consequently three online registers have been established - DOOR for foodstuffs, E-BACCHUS for wines and E-SPIRIT-DRINKS.13 For present purposes, the following registration requirements are relevant: (a) who may apply; (b) the requirement for a product specification, also known as a qualification document, cahiers des charges or code of practice; (c) identifying inspection bodies to test for compliance with the product specification; (d) examination by public authorities; and (e) the consequences of registration (scope of protection).

Regulation 1151/2012 requires that applicants should be groups, which include "any association, irrespective of its legal form, mainly composed of producers or processors working with the same product" (Article 3(2)). They can apply for the name to be registered as a GI (Article 8(1)(a); Article 49(1)) and upon registration, any producer satisfying the production requirements may apply to use the GI (Article 46). In 
exceptional circumstances, individual commercial entities may apply for registration (Article 49(1)). It is evident that the process is designed with inclusivity in mind after the GI has been registered. GI protection should not fall foul of competition or antitrust law and be open to all who meet the registration criteria (Recital 57). However the Regulation is silent on whether the group making the initial application - effectively setting the rules of the game - legitimately represents the interests of the supply chain. While there is no formal examination of this aspect, a recent report by UNIDO emphasises that inclusive and transparent representation from all relevant links in the product supply chain is a crucial precondition for successfully delivering on a GI's development potential (Ackerman \& Russo, 2010). This blind spot in the registration process is flagged up to demonstrate that it has inherent limitations. Further details on the activities of applicant groups are found in Article 45. These include monitoring the quality and authenticity of their members' products; protecting rights to the exclusive use of the GI through litigation; developing information and promotion activities directed at consumers; ensuring compliance with the product specification; and improving supply chain performance, by providing advice to individual producers. This reflects the experiences of Southern European countries, where such groups have been in operation for several decades - prominently, the French inter-professional syndicate, Italian Consorzio and Spanish Consejo Regulador. ${ }^{14}$

Groups qualifying as applicants must submit a number of details as part of the application dossier (Article 8), such as the name and correspondence address of the applicant organisation; details on inspection bodies which test for compliance; and most importantly, detailed information relating to the product specification (Article 7). ${ }^{15}$ This includes:

- The name or designation to be protected, as it has been used in the language(s) historically used to describe the product (for e.g. Parmigiano Reggiano in Italian).

- A product description, covering "the raw materials, if appropriate, as well as the principal physical, chemical, microbiological or organoleptic characteristics of the product".

- The definition of the geographical area, which is "linked" to or causally determines the product's quality or its reputation and evidence that the product originates in this specific place, region or (exceptionally) country.

- A description of the method of obtaining the product and "where appropriate, the authentic and unvarying local methods as well as information concerning [restrictions on] packaging".

- Details on the link between the region of origin and its causal influence upon the product, for either of the two types of GIs protected in the EU - a product's quality or characteristics for Protected Designations of Origin (PDO), defined in Article 5(1) (essentially perceived to be a stronger form of link); or it's given quality, reputation 
or oth.er characteristic for Protected Geographical Indications (PGIs), defined in Article 5(2) (perceived to be a weaker form of link). Further details on the link requirement are provided in an online guide to GI applicants (European Commission).

- Details of the authorities verifying compliance with the product specification

- Any specific labelling rule for the product in question

The significance of these product specification requirements is considered in Section 4 below, which makes the case that there is ample room for ambiguity when fulfilling these requirements, thereby calling into question the value of the certification guarantee. Section 4 also considers the operation of inspection arrangements within the EU in greater detail.

Once this information is submitted, examination in the EU involves a two stage process. An application is initially filed before a national (public) authority where substantive examination occurs. This is considered to be a more thorough review, since national authorities investigate whether the submission is justified and meets the conditions set out in the Regulation (Article 49). The application is also published nationally so that affected parties within the country of origin may object. Decisions taken on registrability can be reviewed by national judicial authorities or administrative tribunals (Articles 4951). On successful completion of this stage the application is forwarded to the European Commission for formal examination, on the relatively restricted basis that the application is not manifestly incorrect. This scrutiny is based solely on the documents provided by the Member State, "in order to check that [the application] is justified and that it meets the conditions of the... scheme". (Article 50). Advocate General Alber identifies the logic behind this: "The point of that division of powers is that examination of an application for registration requires, to a great extent, detailed knowledge of matters particular to the Member State concerned, matters which the national authorities are best placed to check" (Société Ravil v Société Bellon Import [2003], para 87]. If the Commission is satisfied, the application is once again published at the EU level and open to objections for 6 months. If there are no objections, or these are unsuccessful, the GI proceeds to registration. ${ }^{16}$ Once GIs are registered, they can subsequently be amended (Article 53).

Two features are noteworthy about this two-stage process. First, even within the EU there exists a diverse range of national registrars, which results in different levels of experience and depths of engagement. "Member States differ in terms of the nature of the institutions having the main responsibility for the administration of the PDO/PGI scheme. Such variation... is one of the main sources of differences in implementation across the EU" (London Economics, 2008, pp. 63-64). The institution most commonly responsible for administration is a public authority linked to the food or agricultural sector, but some countries also involve their Patent or Intellectual Property Offices. Second, only some EU 
Members have an independent body which advises applicants. Otherwise the registrar is involved both in helping applicants prepare their submissions as well as subsequently examining them (London Economics, 2008, pp. 68). The need for an arms-length requirement has been noted in other countries as well. In the Indian context Rangnekar (2009, p.48) observes that the active engagement of the GI registry has given rise to concerns about its objectivity. "The enabling role of the Registry and its informal consultations proved to be useful in assembling the GI application. However, to what extent did this communication compromise the quality of assessment of the GIapplication?... A number of aspects of Feni were neglected in the two consultative group meetings that took place". It is questionable practice to have national institutions responsible for both facilitating applications and examining them, since this creates the potential for a systemic bias in favour of GI applicants.

Finally, registered GIs enjoy an expansive scope of protection within the EU. Under Article 13 , the following are prohibited: direct or indirect use on dissimilar goods, which exploits the reputation of the protected name (e.g. referring to sparkling water as "the Champagne of mineral waters"); any misuse, imitation or evocation, including translations (e.g. Parmesan) or qualified uses such as "Prosciutto di Parma-style ham"; and broadly defined false or misleading uses. Once protected, an additional advantage is that registered names "shall not become generic" or the common name for a type of product e.g. cheddar (Articles 3(6) \& 13(2)). Additionally, EU Member States must provide administrative assistance for the enforcement of these rights (Articles 13(3) \& 38). As a final point, registered rights holders are in an advantageous position vis-à-vis conflicts with privately owned trademarks that incorporate the GI (Article 14; see also Gangjee, 2007). Registration is therefore clearly beneficial to GI applicants since a suite of powerful exclusionary rights become available.

\section{CERTIFICATION AND ITS AMBIGUITIES}

As Section 2 has established, certification can redress informational asymmetry and provide credible guarantees to consumers. An effective certification signal is also the prerequisite for achieving a range of broader developmental goals. Section 3 identifies the key stages of registration, where detailed information is provided by the applicant to verify provenance and authentic (i.e. historic and consensually developed) methods of production. The registration process endeavours to verify this information. With an account of these formal foundations in place, how is this regime operationalised in practice? As part of an extensive reassessment of agricultural quality policy, the EU's GI regime has been comprehensively reviewed in recent years. With international trade obligations reducing the scope for direct agricultural subsidies, the EU has prioritised 
developing the capacity to compete on the basis of quality: "As globalisation spreads, products from emerging countries with low production costs are putting greater pressure on EU farmers. There is growing competition for both agricultural commodities and value-added products. Faced with these new commercial challenges, the EU farmers' most potent weapon is 'quality"' (European Commission, 2008, p. 4). While quality includes baseline measures such as safety, hygiene and product composition information, it extends to value-added attributes like provenance, local savoir-faire and distinctive quality. The EU therefore sought to improve the communicative efficiency of these quality schemes, by increasing the coherence of its policy instruments through consolidation as well as reducing complexity for both applicants and consumers (European Commission, 2009a).

A proposal emerged to streamline existing legislation on agricultural product quality into a single instrument (European Commission, 2010). It was accompanied by a detailed impact assessment on the proposed changes for GI protection (European Commission, $2009 \mathrm{~b}$ ) and incorporated insights from the review of the European GI system in operation (London Economics, 2008). During this period, the effectiveness of the GI regime was independently scrutinised by the European Court of Auditors (2011). The EU also commissioned quantitative research into the economic impacts of GI protection (Chever, Renault, Renault \& Romieu, 2012). This cumulatively laid the groundwork for Regulation 1151/2012. From this process, three sets of findings emerge which are relevant for our purposes: (a) What do the official PDO and PGI symbols convey to consumers? (b) How effectively is the link to origin and authentic or traditional methods of production guaranteed by certification? (c) How effective is the regime for inspecting compliance?

\section{(a) What does formal Gl certification convey to European consumers?}

As we will, see the short answer to this question is: presently, very little. First the existence of two different forms of GI certification in the EU - the PDO and PGI - needs to be explained. Prior to the adoption of a pan-European legal framework in the form of Regulation 2081/92, two national-level approaches to GI protection existed (Gangjee, 2012a, pp. 224-231). One was the distinctive, terroir-inspired appellation system associated with Southern European (wine-producing) countries, which called for an objectively or qualitatively demonstrable link to the region of origin. Once this requirement was satisfied, broad protection was available. The terroir approach formed the basis for the PDO. The other was a reputation-protection model associated with Northern European jurisdictions and incorporated within broader legal regimes regulating unfair competition, consumer protection or trademark registration. Here 
protection sought to preserve the meaning of the sign for a specific audience i.e. it was more subjective. In the paradigmatic case, an unauthorised commercial operator made misleading use of a geographical sign, which led to consumer confusion about the origin of the product and gave rise to a legal claim. This was the inspiration for the PGI. In the early 1990s, Regulation 2081/92 attempted a compromise by incorporating both approaches, as reflected in its introductory Recitals: "existing practices make it appropriate to define two different types of geographical description, namely protected geographical indications and protected designations of origin". Over the past two decades, the EU has used two symbols to represent this "distinct, yet equal" status for PDOs (Fig. 1) and PGIs (Fig. 2). ${ }^{17}$


But what information do these symbols convey to consumers? The response to this question has two components - (a) general awareness or recognition of these symbols and (b) comprehending their specific meaning. At present general consumer awareness of these logos is low, since their use on qualifying products was made compulsory only in 2009, where the product was marketed under the registered name (Profeta, Balling, Schoene \& Wirsig, 2009, p. 630). This is confirmed by a survey, which revealed that just $8 \%$ of shoppers recognised either the PDO or PGI symbols (London Economics, 2008. p. 154). While there was higher recognition amongst shoppers in Greece (54\%) and Italy (16\%), in the remaining 25 EU Members on average only 5\% recognised these symbols. This corresponds with previous findings in the broader food label recognition literature, suggesting low levels of awareness for such types of food certification labels in general. The survey analysis concluded: "across the EU27, 7\% of main shoppers are aware of, and have at least some understanding of PDO/PGI symbols" (London Economics, 2008, p. 162). The European Economic and Social Committee (2008, para 3.1.8.1) noted that "recognition of European certification schemes and their logos and labels is still inadequate and very patchy. According to a report by the International Centre for Advanced Mediterranean Agronomic Studies... 80 \% of European citizens have never heard of PDOs and $86 \%$ have never heard of PGIs. However, when the same question was asked with reference to corresponding national designations (e.g. the Spanish denominación de origen or the French appellation d'origine controlée) considerably more people were familiar with them. There is clearly a problem at [the] EU level of 
promoting products and making them recognisable to the consumer". As an illustration of a Northern European context less familiar with GIs, research on Hessian apple wine in Germany suggests that the majority of consumers are unaware of the PGI logo or the attributes being certified (Teuber, 2011b). This is reiterated in a survey-based evaluation across 6 European countries, which confirmed a relatively high level of PDO awareness in France, Italy and Spain - countries with a tradition of GI protection - but a considerable gap in PGI awareness in these countries and generally low awareness of GIs in Belgium, Norway, Poland - countries without such a tradition (Verbeke, Pieniak, Guerrero \& Hersleth, 2012, pp. 226-227). The European Court of Auditors (2011, pp. 25-33) concluded that previous efforts to remedy this were inadequate. EU-funded information campaigns by trade organisations to raise the profile of the GI regime are unlikely to improve the situation. This vulnerability is now directly addressed by Regulation $1151 / 2012$, which emphasises that use of the logos should be made obligatory "in order to make this category of products, and the guarantees attached to them, better known to consumers and in order to permit easier identification of these products on the market, thereby facilitating checks" (Recital 28). Article 12(3) now mandatorily requires the use of the symbols along with the registered name. Article 44 also reserves the use of such symbols only for products which legitimately qualify for them.

While compulsory use will increase the general awareness of these symbols over time, the other problem of interpreting their specific meaning remains. Evidence suggests that of the $8 \%$ of EU consumers who recognised the symbols, about a quarter "erroneously believed that the PDO or PGI symbol referred to a product being produced in an environmentally friendly way (a characteristic of Organic products), or using a traditional recipe" (London Economics, 2008, pp. 160-161). Again from within this 8\%, only $51 \%$ correctly identified that the product is produced in one specific area, while $42 \%$ correctly identified that it signalled compliance with a product certification regulated by a controlling body. Other studies confirm that a swarm of overlapping associations are triggered by these designations, such as superior quality, healthiness, safety, artisanal production, a cultural heritage dimension, environmental friendliness, nostalgia and rustic imagery as well as associations with rural development (Tregear, 2002, pp. 9-10; Verbeke, Pieniak, Guerrero \& Hersleth, 2012). There are evidently very mixed messages as to the precise attributes being certified. Yet the theoretical foundations - and their judicial endorsement - set out in Section 2 assume that examination and certification by public authorities enables a clear signal to reach consumers. The relative obscurity of the very symbols conveying this certification information fundamentally impedes this outcome. As Crespi and Marette (2003, p. 86) remind us, a "regulator must keep in mind that for an uninformed public, a signal such as a label may provide little relevant information. It is therefore crucial to determine whether consumers find the proposed 
label useful... Consumers' ability to understand the label is a crucial point that may get lost in any discussion of costs and benefits".

\section{(b) Flexibility within the product specification}

A close and relevant link with the region of origin is crucial for achieving territorially based development strategies. The details of this link are contained in the product specification or code of practice that must be adhered to by all those using the GI. These

"are important to rural development as it is through these codes that the activities most beneficial to the socio-economic well-being of an area may be assured" (Tregear, Arfini, Belletti \& Marescotti, 2007, p. 14). The specification describes (i) the product and its attributes (e.g. distinctive organoleptic qualities or chemical characteristics); (ii) the method of production (e.g. raw materials to be used; stages of production; packaging requirements); (iii) the defined region within which it must be procured or produced; and (iv) evidence of a causal link between the product and region of origin (Vandecandelaere, Arfini, Belletti \& Marescotti, 2009-10, pp. 49-92; Belletti \& Marescotti, 2011b; pp. 38-39; Réviron, Thevenod-Mottet \& El Benni, 2009, p. 15). So how rigorously does the certification system scrutinise this product specification to ensure that it guarantees regional provenance and traditional methods of production?

\section{(i) Guaranteeing origin?}

At the core of the legal justification for GI protection in the EU is a guarantee of geographical origin to consumers. Yet for both the PGI and the PDO, there are exceptions to this origin requirement in Regulation 1151/2012. For the PGI, it is sufficient if any one of the production steps (production, processing or preparation) takes place within the region of origin (Article 5(2)(c)). For the PDO, raw materials (specifically, live animals, meat or milk) may come from "a geographical area larger than, or different from, the defined geographical area", provided that (a) this external territory is also delimited, (b) there are special requirements for the production of these raw materials as well as (c) control arrangements to ensure these requirements are met (Article 5(3)). Similar flexibilities were previously available in Regulation 2081/92 and Regulation 510/2006. An illustration of this is provided by the UK's Stilton Cheese PDO product specification: "Originally, milk for the manufacture of STILTON cheese was drawn exclusively from local farms near the producing plants. But as production has grown and in particular as demand for STILTON cheese has increased around the Christmas period, so at times of the year milk will be drawn from further afield and outside the three [specified] counties. However, even today the majority of milk used for the manufacture of STILTON cheese still comes from within the three counties". ${ }^{18}$ The justification for external sourcing is 
based on historic restrictions - milk quotas - which led to a decline in local supply. Therefore milk is sourced from neighbouring regions but monitored for quality control. Rippon (2013, p. 278) notes that producers of the Melton Mowbray Pork Pie opted for PGI registration since it "encourages malleable production practices", allowing for flexibility to source the pork form outside the region when needed. Similarly for the reputed Prosciutto di Parma, the "raw materials originate from a larger geographical area than the production area [Province of Parma], which covers the following administrative regions: Emilia-Romagna, Veneto, Lombardy, Piedmont, Molise, Umbria, Tuscany, Marche, Abruzzi, Lazio (Italy)". ${ }^{19}$ From the producers' perspective, this flexibility is essential to ensure consistent and adequate supplies of raw materials, especially in situations where there is growing demand. However from a consumer's perspective, this could cast doubts upon the reliability of the certification signal.

While consumers have not previously raised concerns about this aspect, it could relate to their general lack of awareness of the PDO and PGI labels. Upon becoming aware of this flexibility concerning raw materials German, Italian and Belgian consumer groups expressed concerns that consumers are being misled, especially as regards PGIs (European Commission, 2009b, Annex B, pp. 38-42). While in some cases consumers would be aware that only one stage of production took place in the designated region, in others this would go against their expectations. The EU review (London Economics, 2008, pp. 90-91) concluded: "The bottom line is that the non-information on raw material origin used in PGI may, in some cases, be a source of confusion for consumers... to avoid any potential consumer confusion and detriment, it would be useful if, on the packaging of a PGI product, there was greater clarity about the provenance of the origin of the raw materials used in the PGI product". Echoes of this far more qualified and porous guarantee of origin are found in other national geographical indications regimes as well. Rangnekar (2009) refers to the sourcing of cashew apples from outside Goa to compensate for years with a lower crop yield. The point is that certification systems which are ostensibly designed to guarantee geographical origin permit this flexibility; yet consumers are largely unaware of this.

\section{(ii) Guaranteeing authenticity or traditional methods of production?}

Within the legal literature, we find assertions that "at the conceptual core of GIs is a claim about authenticity and heritage" (Raustiala \& Munzer, 2007, p. 346). In terms of guaranteeing this authenticity, Regulation 1151/2012 requires that information be provided about the traditional method of production but the level of detail is left to the discretion of the applicant group. Article 7(1)(e) merely calls for "a description of the method of obtaining the product and, where appropriate, the authentic and unvarying 
local methods as well as information concerning packaging". Here the "lack of precise rules on the definition of the production method may mean that the applicant group has significant influence over the detail of the production method' (London Economics, 2008, p. 81). Unless objections are raised at the national level, there is no mechanism for mandatory state oversight during the drafting stage, which is yet another blind spot in the certification process. In an ideal scenario, codes are drawn up via a consultative process with input from across the supply chain, guided by norms of stakeholder inclusivity and transparency resulting in agreement concerning the traditional production methods to be followed. Yet in practice, individual actors often disagree, "particularly where they are heterogenous and multi-sectoral in nature" (Tregear, Arfini, Belletti \& Marescotti, 2007, p. 14). Tradition and heritage are malleable resources, being actively reconstructed during the drafting process. These contestations over authenticity could play out in different ways: (1) Scale, where larger firms may opt for a more industrial approach as opposed to producers favouring artisanal, labour intensive production methods which limit volumes (London Economics, 2008, p. 81; Rangnekar, 2009). (2) Often related to this, the sourcing of raw materials from outside the region, or compromising on minimum age or local varietal requirements as Bowen (2010a) has documented in the case of Tequila, where pressure from multinational spirit producing firms distorted the definition of what constituted a sufficiently "mature" agave cactus. (3) Defining the region of origin strategically, where boundaries may be delimited in an exclusionary manner by those initiating the product specification. This is more likely in the case of the PGI where the link to origin may be based on (historic) reputation alone. Boundaries are more open to manipulation in the absence of geologically or climaticallydetermined limits, whereby attempts could be made to carve out competitors (Gangjee, 2006; Rippon, 2013). Tradition is therefore a contested analytic category. Recent research emphasizes the need to avoid a frozen or static understanding - restrictively codifying practices which then become "Disneyfied" or merely "living museums" (Bowen \& De Master, 2011) - as well as being attentive to the effects of unequal power relations during the drafting process (Bowen 2010a; Rangnekar, 2011).

While in some cases a particular dominant vision of the production method will be driven through, in other situations drafting techniques have arisen to accommodate these divergent views. (1) Where there is a dispute over the method of production (for e.g. one sub-group favouring more artisanal, historically accurate or elaborate production techniques) further distinctions may be made within a class of products, with separate registration applications for each. So the PDO Aceto Balsamico Tradizionale di Modena is distinguished from the PGI Aceto Balsamico di Modena, on the basis that the former requires the cooked grape must, from which the famous balsamic vinegar is made, to be aged for at least 12 years while the grapes themselves are sourced from a defined geographical region. ${ }^{20}$ (2) For some products a number of variants exists, which share a 
broad "family resemblance". In such situations an overly restrictive or tightly defined specification could serve to inhibit the historic diversity of production practices. Using the example of the Chevrotin PDO for goat's cheese, Bérard \& Marchenay (2008, pp. 2829) refer to the possibility of an umbrella GI specification, which is suitably abstract and can accommodate variations in the size of the cheese, the extent to which high-pasture goat's milk is used, the process of maturing and the colour of the rind etc. (3) In other instances, the product specification lacks detail only for specific stages of the production process, where agreement may not have been possible (Rangnekar, 2011; Mancini 2013). Alternatively, a conscious decision may have been taken to leave individual producers the room to manoeuvre (for e.g. only setting a minimum meat content requirement for a pork pie but not an upper limit), so that they can continue to competitively distinguish themselves within the broader group (Rippon, 2013, p. 278). (4) A more extreme version of this would be strategic silences, where controversial stages are completely excluded from the specification, leaving this entirely to the discretion of individual producers. (5) Finally, if the consensus around production techniques evolves, it is possible to amend the product specification. ${ }^{21}$ Bromberger (2006) identifies changes in market conditions and consumer tastes, as well as the imposition of modern sanitation norms (e.g. pasteurization), as the usual suspects behind such amendments. The growing body of empirical case studies suggests that not only do production techniques evolve, the process of arriving at an official product definition and method is usually controversial. Tradition and authenticity are moving targets - the extent to which any certification system can formally guarantee them is doubtful at best. Examination by public authorities does not extend to scrutinizing these "behind the scenes" choices, so it is naïve to accept that the registration system actually verifies "the authentic and unvarying local methods" of production (Art 7(1)(e) of Regulation 1151/2012).

\section{(c) Is the inspection regime effective?}

Inspection and monitoring ensure the credibility of a certification system. In the EU context, this follow up activity has two dimensions. Regulation 1151/2012 requires that GI applicants identify a suitably accredited inspection body which tests "internally" within the group of users for compliance with the product specification (Article 36 and 37). It also imposes "external" monitoring obligations to prevent the misuse of the GI by third parties (Articles, 36, 38-39). There is a further responsibility to generate national level annual reports detailing these monitoring and enforcement activities (Article 40). The general tightening up of these obligations was considered necessary, since the review by London Economics (2008, pp. 73-75) found that despite similar legal obligations being imposed under the previous Regulation 510/2006, there was considerable variation in practice across the EU Membership. As regards "internal" verification, Regulation $510 / 2006$ left the choice as to public or private certification bodies to Member States. 
While this choice is not objectionable per se, the result was a lack of harmonisation in the nature and frequency of inspection. Thus in France an independent body would inspect the control or compliance procedures of the applicant producer group (the certifier's competence to certify), while in Italy, 35\% of registered producers belonging to the consortium would be checked each year by an independent certifier. In some countries there would be only one GI-specific annual inspection while in others, inspection occurred as part of general food controls, which were orientated towards baseline safety and quality requirements. Consequently the coverage of the checks, their frequency and the parts of the supply chain being inspected all varied considerably. The European Court of Auditors (2011, p. 16) found that while in one Member there were entry level compliance checks when first entering the GI scheme (did a new producer satisfy the product specification requirements?), all users of the GI were sampled for inspection purposes and there was an obligation for all users of the GI to be registered, none of these checks were necessary in another Member. As regards "external" surveillance to prevent confusing uses or free riding, the EU's Impact Assessment (European Commission, 2009b, Annex B, pp. 37-38) noted that only "two Member States were identified as employing resources specifically dedicated to the protection of PDO/PGI names in the market place: in the first one, one official makes routine inspections of every supermarket on a monthly basis to detect fraudulent practices related to PDO/PGI products. In the second, some enforcement activities are undertaken by regional authorities and [applicant bodies of producers]". Otherwise the GI regime was incorporated within the general enforcement of Food Law standards in the EU, but here the emphasis was on hygiene or safety checks, as opposed to misuses which infringed IP rights. Public authorities would also mainly focus on protecting national GI products, as opposed to all registered EU GIs (European Court of Auditors, 2011, pp. 18-19). While private enforcement through litigation by applicant groups remained an option, enforcement by public authorities was generally revealed to be unsatisfactory because it was incorporated within a broader food quality regulation framework having its own distinct priorities. Therefore both the internal and external dimensions of verification - while still considerably more prescriptive than trademark law alternatives - were found to have serious inadequacies.

\section{CONCLUSION: THE TURN TO THE PRODUCT SPECIFICATION}

Certification is justified because of its ability to redress informational asymmetries and benefit consumers. For GIs, certification by public authorities under a sui generis regime is considered to be sufficiently rigorous and therefore more appropriate for satisfying consumer preferences as well as achieving territorial development strategies. However the previous Sections of this paper have argued that there are considerable gaps between theory and practice: (1) While individual GI products are well known, the formal 
certification system is relatively invisible. Despite the passage of two decades, the majority of consumers remain unaware of the existence of PDO and PGI symbols, or are unfamiliar with their specific meaning; (2) The guarantee of provenance is somewhat tentative, since different stages of production or raw materials may be sourced from outside the defined geographical region; (3) Similarly, the guarantee of authenticity or production in accordance with traditional methods emerges as far more contingent, since this ultimately depends on the content of the product specification. The process of drafting this code usually falls outside the purview of examination by certification authorities, unless it is formally challenged at the national level. (4) Finally the extent to which there is reliable follow up inspection and verification - which undergirds the credibility of certification - varies across EU members. This criticism is not intended to undermine sui generis protection systems administered by public authorities. They continue to be more rigorous and prioritise the regional link requirement when contrasted with trademark law alternatives. The point being made is that we need to be more realistic in our expectations. The certification capabilities of such sui generis GI regimes are limited because they can only scrutinise the materials presented before them. They have significant blind spots. Therefore it would be a mistake to assume that formal legal recognition as a GI inevitably ensures provenance and authenticity to the extent necessary in order to achieve developmental goals or satisfy consumer expectations. In many cases, something more is required.

For that reason, this paper concludes by shifting its focus, from the design of registration systems to the design of the individual product specification. This has emerged as a site of interest because it creates the potential for interactions between a number of different actors - those who participate in the various stages of the product's supply chain, state authorities at various levels (central, local), NGOs or civil society organisations, intergovernmental organisations and scholars or policy researchers. While debates till date have involved contrasts between state-supported prescriptive GI systems and more permissive, privately organised ones, recent scholarship moves beyond this binary, system-level analysis to study individual codes of practice and the full spectrum of those involved in instituting, developing and sustaining them. To begin with, there are local NGOs with expertise in rural policy implementation who facilitate the establishment of GIs (Vandecandelaere, Arfini, Belletti \& Marescotti, 2009-10, p. 6; Hartman, 2012). Support is also provided by international NGOs such as the Organization for an International Geographical Indications Network (OriGIn) and the International Trade Centre, who provide toolkits, checklists, practical manuals and other resources for producers. ${ }^{22}$ Intergovernmental organisations such as the FAO, UNCTAD and WIPO have been increasingly active in this area, documenting experiences and organizing gatherings to disseminate research. Meanwhile researchers have played a crucial role: CIRAD ${ }^{23}$ is an influential French research institution with an interest in development and agricultural 
issues, which provides international consultancy and advice to developing countries. Two now-concluded European research projects - DOLPHINS and SINER-GI -consolidated expertise, identifying researchers as well as practitioners with relevant experience and drew together research findings. ${ }^{24}$ The emergence of these influential actors and the emphasis on the product specification moves the debate beyond the tired binary choice of market (trademarks) versus state (sui generis protection) as the best method of actualising GI potential.

A key difference lies in the emphasis on facilitating those social processes and relationships, cultural interactions, practices and informal institutions that sustain successful GIs and which cannot be entirely reduced to documentary form in a technical specification. It is not just about identifying the product with sufficient precision but also identifying processes which enable egalitarian participation across the supply chain and informed debate around the product. Here the preferred theoretical lens is collective action, which studies the actions undertaken by groups (or their representatives) in pursuit of their members' perceived shared interests. Of particular interest is the role of formal and informal institutions which support and co-ordinate such action (Ostrom, 2007; Vanni, 2014, pp. 21-26, Biénabe, Kirsten \& Bramley 2013). One synthesis of lessons from the case studies suggests that four components are essential for long term success: (1) Strong organizational and institutional structures to maintain, market, and monitor the GI; (2) Equitable participation among the producers and enterprises in a GI region, where costs, benefits and decision making is shared; (3) Strong market partners committed to promote and commercialize the product over the long term; (4) Effective legal protection, beginning with a robust domestic GI regime (Giovannucci, Josling, Kerr, O'Connor \& Yeung, 2009, pp. xviii-xix). The importance of institutional structures is confirmed by other studies as well. In the context of South African Rooibos tea, it was concluded that the "organization and leadership of the governance structure is key" (Kop, Sautier \& Gerz, 2006, pp. 93-94). Fostering trust and co-operation between different supply-chain actors is crucial to the success of a GI. Bowen (2010b, pp. 228-229) attributes the success of the Comté cheese GI to "(1) a strong sense of leadership, (2) a collective vision oriented around sustainability and quality, and (3) an organizational process that is perceived to be fair and representative of all supply-chain actors". By contrast the collective body for Tequila was perceived as a vehicle for the interests of transnational liquor companies. In a similar vein, Torre (2006) identifies the formalization of relationships through legally enforceable contracts leading to greater predictability, effective management and governance structures for the collective organization and consequently organizational trust in the rules (governing membership, compliance with the specification etc). Additional topics of interest include the motivation to join such collective organisations (O'Reilly, Haines \& Arfini, 2003), contrasts between the different types of co-ordination models (for e.g. interprofessional 
associations with membership across the supply chain versus a professional association representing a single, perhaps dominant, part of it) (Réviron \& Chappuis, 2011) and the extent to which knowledge transfer is successful, since these networks provide a context for learning by doing (Réviron, Thevenod-Mottet \& El Benni, 2009, p. 18).

If the certification system has the product as its object of regulation, this recent turn to the product specification prioritises institutional support for ongoing processes, practices and relationships. Through the identification and sharing of best practices enabled not only by public authorities but by a broader range of actors - there is the potential for GIs to meaningfully remain anchored to places and deliver on developmental goals. 


\section{References}

Ackermann, N., \& Russo, F. (2010). Adding value to traditional products of regional origin: A guide to creating a quality consortium. United Nations Industrial Development Organization, Vienna.

Akerlof, G. A. (1970). The market for 'lemons': quality uncertainty and the market mechanism. The Quarterly Journal of Economics, 84(3), 488-500.

Arrow, K. J. (1963). Uncertainty and the welfare economics of medical care. The American Economic Review, 53(5), 941-973.

Augustin-Jean, L. (2012). Standardization vs Products of Origins: What Kinds of Agricultural Products Have the Potential to Become a Protected Geographical Indication?. Geographical Indications and International Agricultural Trade: The Challenge for Asia, 48.

Belletti G, Burgassi T, Marescotti A et al. (2007). The effects of certification costs on the success of a PDO/PGI. In Theuvsen L, Spiller A et al. (Eds) Quality Management in Food Chains. Wageningen Academic Publishers, Wageningen, 107-123.

Belletti, G., \& Marescotti, A. (2011a). Origin products, geographical indications and rural development. In E. Barham \& B. Sylvander (eds). Labels of origin for food. Local development, global recognition, 75-91.

Belletti, G., \& Marescotti, A. (2011b) Monitoring and evaluating the effects of the protection of

Geographical Indications: A methodological proposal. In Swiss Federal Institute of Intellectual Property (Ed.), The effects of protecting geographical indications: Ways and means of their evaluation. Bern, Switzerland: Swiss Federal Institute of Intellectual Property, 1-11.

Bérard, L., \& Marchenay, P. (2008). From localized products to geographical indications. Awareness and Action. Ressources des Terroirs-CNRS.

Beuchelt, T. D., \& Zeller, M. (2011). Profits and poverty: Certification's troubled link for Nicaragua's organic and fairtrade coffee producers. Ecological Economics, 70(7), 13161324.

Biénabe, E., Jordaan, D., \& Bramley, C. (2013). Private versus public quality schemes for origin-labelled products: Insights from the Karakul pelts and Camdeboo mohair industries. In C. Bramley, E. Biénabe \& J. Kirsten, Developing Geographical Indications in the South: The South African experience. Springer Netherlands, 73-93.

Biénabe, E., Kirsten, J., \& Bramley, C. (2013). Collective Action Dynamics and Product Reputation. In C. Bramley, E. Biénabe \& J. Kirsten, Developing Geographical Indications in the South: The South African experience. Springer Netherlands, 51-72. 
Bowen, S. (2010a). Development from within? The potential for geographical indications in the global South. The Journal of World Intellectual Property,13(2), 231252.

Bowen, S. (2010b). Embedding local places in global spaces: geographical indications as a territorial development strategy. Rural Sociology, 75(2), 209-243.

Bowen, S., \& De Master, K. (2011). New rural livelihoods or museums of production? Quality food initiatives in practice. Journal of rural Studies, 27(1), 73-82.

Bramley, C., Biénabe, E., \& Kirsten, J. (2009). The economics of geographical indications: Towards a conceptual framework for geographical indication research in developing countries. The Economics of Intellectual Property, 109.

Bromberger, B. F. (2006). Aged, but not old: Local identities, market forces, and the invention of "traditional" European cheeses. In R. Hosking (Ed.), Authenticity in the Kitchen: Proceedings of the Oxford Symposium on Food and Cookery 2005. Oxford Symposium 89.

Chever, T., Renault, C., Renault, S., \& Romieu, V. (2012). Value of production of agricultural products and foodstuffs, wines, aromatised wines and spirits protected by a geographical indication (GI). Final report.

Crespi, J. M., \& Marette, S. (2003). Some economic implications of public labeling. Journal of Food Distribution Research, 34(3), 83-94.

Commission v. Germany (Case 12/74) [1975] European Court Reports 181.

De Roest, K., \& Menghi, A. (2000). Reconsidering 'traditional' food: the case of Parmigiano Reggiano cheese. Sociologia Ruralis, 40(4), 439-451.

Delhaize v. Promalvin (Case C-47/90) [1992] European Court Reports I-3669.

Deppeler, A., Stamm H. \& Thévenod-Mottet. (2011). Why evaluate the effects of protection of GIs?. In Swiss Federal Institute of Intellectual Property (Ed.), The effects of protecting geographical indications: Ways and means of their evaluation. Bern,

Switzerland: Swiss Federal Institute of Intellectual Property, 1-11.

Deselnicu, O. C., Costanigro, M., Souza-Monteiro, D. M., \& McFadden, D. T. (2013). A Meta-Analysis of Geographical Indication Food Valuation Studies: What Drives the Premium for Origin-Based Labels?. Journal of Agricultural \& Resource Economics, 38(2).

European Commission. Guide to applicants for completion of the single document. Available at: http://ec.europa.eu/agriculture/quality/schemes/guides/guide-forapplicants en.pdf

European Commission. (2008). Green paper on agricultural product quality: Product standards, farming requirements and quality schemes. Document No. COM(2008) 641 final. Brussels. 
European Commission. (2009a). Communication from the Commission to the European Parliament, the Council, the European Economic and Social Committee and the Committee of Regions on agricultural product quality policy. Document No. COM(2009) 234. Brussels.

European Commission. (2009b). Staff working document accompanying the communication from the Commission to the European Parliament, the Council, the European Economic and Social Committee and the Committee of Regions on agricultural product quality policy. Impact Assessment Report. Document No. SEC(2009) 670.

European Commission. (2010). Proposal for a regulation of the European Parliament and of the Council on agricultural product quality schemes. Document No. COM(2010) 733 final. Brussels.

European Commission. (2011). Green paper on promotion measures and information provision for agricultural products: a reinforced value-added European strategy for promoting the tastes of Europe. Document No. COM/2011/0436. Brussels.

European Court of Auditors. (2011). Do the design and management of the geographical indications scheme allow it to be effective?. Special Report No 11. Luxembourg.

European Economic and Social Committee. (2008). Opinion on Geographical indications and Designations. Official JournalC 204/57.

Evans, G. (2013). The protection of geographical indications in the European Union and the United States under sui generis and trade mark systems: signs of harmonization? Intellectual Property Quarterly. 18-46.

Exportur v LOR SA and Confiserie du Tech (Case C-3/91) [1992] European Court Reports I-5529.

(FAO) Food and Agriculture Organisation (2008). Promotion of Traditional Regional Agricultural and Food Products: A Further Step towards Sustainable Rural Development. 26 ${ }^{\text {th }}$ FAO Regional Conference for Europe, 26-27 June 2008 (ERC/08/4). Available at: ftp://ftp.fao.org/docrep/fao/meeting/013/K2473E.pdf (FAO) Food and Agriculture Organisation (2012). Identification of origin-linked products and their potential for development: A methodology for participatory inventories. FAO, Rome.

Gangjee, D. (2006). Melton Mowbray and the GI pie in the sky: exploring cartographies of protection. Intellectual Property Quarterly, 3, 291-309.

Gangjee, D. (2007). Quibbling siblings: Conflicts between trademarks and geographical indications. Chicago-Kent Law Review, 82, 1253-1291.

Gangjee, D. (2012a). Relocating the law of geographical indications (Vol. 15). Cambridge University Press. 
Gangjee, D. S. (2012b). Geographical Indications and Cultural Heritage. WIPO Journal, 4, 92-102.

Giovannucci, D., Josling, T. E., Kerr, W., O'Connor, B., \& Yeung, M. T. (2009). Guide to geographical indications: linking products and their origins. International Trade Centre.

Guy, K. M. (2007). When champagne became French: Wine and the making of a national identity. John Hopkins University Press.

Hartman, E. (2012). A legal and empirical investigation of the implementation of European food quality schemes (PDO, PGI, TSG). Unpublished doctoral dissertation. Bournemouth University, UK. Available at:

http://eprints.bournemouth.ac.uk/20979/1/2012thesisEwaHartman.pdf

Hughes J (2009) Coffee and chocolate: can we help developing country farmers through geographical

indications? Report prepared for the International Intellectual Property Institute, Washington, DC.

Jahn, G., Schramm, M., \& Spiller, A. (2005). The reliability of certification: Quality labels as a consumer policy tool. Journal of Consumer Policy, 28(1), 53-73.

Kingdom of Belgium v Kingdom of Spain (Case C-388/95) [2000] European Court Reports I-3123.

Kop, V. D. P., Sautier, D., \& Gerz, A. (2006). Origin-based products: Lessons for pro-poor market development. Bulletin/Development policy \& practice, (372).

London Economics (2008). Evaluation of the CAP policy on protected designations of origin (PDO) and protected geographical indications (PGI). Final report. Brussels:

European Commission.

Mancini, M. C. (2013). Localised Agro-Food Systems and Geographical Indications in the Face of Globalisation: The Case of Queso Chontaleño. Sociologia Ruralis, 53(2), 180-200.

Marie-Vivien, D. (2010). The role of the state in the protection of geographical indications: from disengagement in France/Europe to significant involvement in India. The Journal of World Intellectual Property, 13(2), 121-147.

Morgan, K., Marsden, T., \& Murdoch, J. (2006). Worlds of Food: Place, Power, and Provenance in the Food Chain: Place, Power, and Provenance in the Food Chain. Oxford University Press.

(OECD), Organization for Economic Co-operation and Development. (2000).

Appellations of Origin and Geographical Indications in OECD Member countries:

Economic and Legal Implications. Document COM/AGR/APM/TD/WP(2000)15/FINAL.

Available at: http://www.oecd.org/. 
O'Connor \& Co. (2007) Geographical indications and TRIPs: 10 years later... Part II Protection of geographical indications in 160 countries around the world. (Report commissioned for EC (DG Trade)).

O'Reilly, S., Haines, M., \& Arfini, F. (2003). Food SME networks: Process and governanceThe case of Parma ham. Journal on Chain and Network Science,3(1), 21-32.

Ostrom, E. (2007). Collective action theory. In Boix, C., Stokes, S. (eds.), The Oxford Handbook of Comparative Politics. Oxford University Press, Oxford, UK, pp. 186-208.

Prado, M. M. (2010). What is Law and Development?. Revista Argentina de Teoria Juridica, 11(1).

Profeta, A., Balling, R., Schoene, V., \& Wirsig, A. (2009). The protection of origins for agricultural products and foods in Europe: status quo, problems and policy recommendations for the Green Book. The Journal of World Intellectual Property, 12(6), 622-648.

Rangnekar, D. (2004). The socio-economics of geographical indications. UNCTAD-ICTSD Project on IPRs and Sustainable Development, Issue Paper, (8).

Rangnekar, D. (2009). Geographical indications and localisation: A case study of Feni. ESRC Report.

Rangnekar, D. (2011). Remaking place: the social construction of a Geographical Indication for Feni. Environment and Planning-Part A, 43(9), 2043.

Raustiala, K., \& Munzer, S. R. (2007). The global struggle over geographic indications. European Journal of International Law, 18(2), 337-365.

Ravil SARL v Bellon Import SARL [2003] (Case C-469/00) European Court Reports I505.

Réviron, S., Thevenod-Mottet, E. \& El Benni, N. (2009). Geographical indications: Creation and distribution of economic value in developing countries. Swiss National Centre of Competence in Research (NCCR) Working Paper, No. 14.

Réviron, S. \& Chappuis, J. M. (2011). Geographical indications: collective organization and management. In E. Barham \& B. Sylvander (eds). Labels of origin for food. Local development, global recognition, 45-62. Cambridge: MA, CAB International.

Ruben, R., \& Fort, R. (2012). The impact of fair trade certification for coffee farmers in Peru. World Development, 40(3), 570-582.

Serra, R. (2007). European Union Policy for High Quality Agricultural Products. Beijing, WIPO International Symposium on Geographical Indications.

Skuras, D., \& Dimara, E. (2004). Regional image and the consumption of regionally denominated products. Urban Studies, 41(4), 801-815.

Soam, S. K. (2005). Analysis of prospective geographical indications of India. The Journal of World Intellectual Property, 8(5), 679-704. 
Société Ravil v Société Bellon Import and Société SPA Biraghi (Case C-469/00) [2003] European Court Reports I-505

Stanziani, A. (2004). Wine reputation and quality controls: the origin of the AOCs in 19th century France. European Journal of Law and Economics, 18(2), 149-167.

Steering Committee of the State-of-Knowledge Assessment of Standards and Certification. (2012). Toward sustainability: The roles and limitations of certification. Washington, DC: RESOLVE, Inc.

Sylvander, B., Allaire, G., Bellotto, G. et al (2006) Les dispositifs français et européens de protection de la qualité et de l'origine dans le contexte de l'OMC : justifications générales et contextes nationaux,

Revue canadienne des sciences regionales, 29(1), 43-54.

Teuber, R. (2011a). Protecting Geographical Indications: Lessons learned from the Economic Literature. In 2011 International Congress, August 30-September 2, 2011, Zurich, Switzerland(No. 116081). European Association of Agricultural Economists. Teuber, R. (2011b). Consumers' and producers' expectations towards geographical indications: Empirical evidence for a German case study. British Food Journal, 113(7), 900-918.

Torre, A. (2006). Collective action, governance structure and organizational trust in localized systems of production. The case of the AOC organization of small producers. Entrepreneurship and Regional Development, 18(1), 55-72.

Tregear, A. (2002) WP4, Link Between Origin Labelled Products and Consumers and Citizens: Final

Report, July 2002. Part I: Synthesis. Concerted Action DOLPHINS (Development of Origin Labelled

Products: Humanity, Innovation and Sustainability). Available at: http://www.originfood.org/cadre/careport.htm (accessed 20 March 2014).

Tregear, A., Arfini, F., Belletti, G., \& Marescotti, A. (2007). Regional foods and rural development: the role of product qualification. Journal of Rural Studies, 23(1), 12-22.

USPTO. 'Geographical Indication Protection in the United States', available at www.uspto.gov/web/offices/dcom/olia/globalip/pdf/gi system.pdf.

Van Ittersum, K., Meulenberg, M. T., Van Trijp, H., \& Candel, M. J. (2007). Consumers' Appreciation of Regional Certification Labels: A Pan-European Study. Journal of Agricultural Economics, 58(1), 1-23.

Vandecandelaere, E., Arfini, F., Belletti, G., \& Marescotti, A. (2009-2010). Linking people, places and products. A guide for promoting quality linked to geographical origin and sustainable geographical indications. Rome: FAO. 
Vanni, F. (2014). Agriculture and public goods: The role of collective action. Springer Netherlands.

Vecchio, R., \& Annunziata, A. (2011). The role of PDO/PGI labelling in Italian consumers' food choices. Agricultural Economics Review, 13(1).

Verbeke, W., Pieniak, Z., Guerrero, L., \& Hersleth, M. (2012). Consumers' awareness and attitudinal determinants of European Union quality label use on traditional foods. Biobased and Applied Economics, 1(2), 213-229.

Warner, C. K. (1960). The winegrowers of France and the government since 1875.New York: Columbia University Press.

Winter, M. (2003). Embeddedness, the new food economy and defensive localism. Journal of rural studies, 19(1), 23-32.

WIPO. (2001). Protection of Geographical Indications: General Introduction, International Protection and Recent Developments. Document No.

WIPO/GEO/CIS/01/1.

WIPO. (2003). Geographical Indications. Document No. SCT/10/4.

WIPO. (2012). Geographical Indications: An introduction Geneva: WIPO Publication No. 952(E). 


\title{
Endnotes
}

\begin{abstract}
${ }^{1}$ The notion of embeddedness, with its emphasis on social relations that are otherwise eclipsed in the context of economic transactions, is usually contrasted with giant food companies and globalised agro-food production models. It has also been subjected to critical scrutiny, since consumer preferences for local chains of production may have as much to do with the defensive politics of localism as with a turn to quality (Winter, 2003; Morgan, Marsden \& Murdoch, 2006).

${ }^{2}$ GI regimes involve certification at two broad levels. First, the distinctive regional product (e.g. Roquefort cheese) needs to be formally recognised as satisfying the definition of a GI and related legal criteria, such as a stabilised and commonly adopted method of production. Secondly, once the formal template or product specification is certified, individual producers need to be inspected and certified, to ensure that their products match up to the specification. While this paper focuses on the first of these stages, both are closely inter-related. A very demanding product specification will make it difficult and expensive for producers to legitimately adopt
\end{abstract} the GI (Belletti, Burgassi, Marescotti et al., 2007).

${ }^{3}$ In the IP law context, sui generis means of its own type or unique. There are two implicit assumptions made here: (1) Such a system of registration-based GI protection is distinct because it does not map onto any of the three major categories of IP - patents, copyright or trademarks. In the case of GIs, we could add that such protection is also distinct from existing systems regulating the use of signs in the marketplace, such as consumer protection legislation or unfair competition law. (2) Having established what they are not, what they do share in common is that such regimes can usually trace their lineage back to late $19^{\text {th }}$ century experiments with the French Appellation d'Origine (AO) and subsequently the Appellation d'Origine Contrôlée (AOC), designed around wines. Directed at regulating grape overproduction and the ensuing fraudulent labeling of wines, the AOC regime was preoccupied with identifying - via a system of bureaucratic recognition - those entitled to legitimately use an appellation while preventing their misuse by unauthorized third parties (Stanziani, 2004; Gangjee, 2012a; pp. 77-126).

${ }^{4}$ As a recent report concludes: 'Of the 167 countries that protect GIs as a form of intellectual property, 111 (including the EU 27) have specific or sui generis systems of GI laws in place. There are 56 countries using a trademark system, rather than or in addition to specific GI protection laws. These countries utilize certification marks, collective marks or trademarks to protect GIs' (Giovannucci, Josling, Kerr, O'Connor \& Yeung, 2009, p. 14).

${ }^{5}$ According to a recent report, the 'recognition of GIs (considered as the specific relation associating a denomination and a product) normally depends on an assessment of their intrinsic value through an arbitration process managed by the state, which explains their particular legal and institutional status... In this context, the role of the state concerning the recognition and management of GIs is still being debated' (Deppeler, Stamm \& Thévenod-Mottet, 2011, p. 2).

${ }^{6}$ Tequila is Registered Appellation No. 669 under the Lisbon Agreement for the Protection of Appellations of Origin and their International Registration, 1958. The register is available at: http://www.wipo.int/ipdl/en/lisbon/ (Accessed on 10 Apr 2014).

${ }^{7}$ However the extent of state involvement in such compliance efforts has varied over time, with the burden of monitoring shifting onto the applicant producer groups in some cases (Marie Vivien, 2010).

${ }^{8}$ The CJEU has subsequently confirmed that the "reputation of designations of origin depends on their image in the minds of consumers. That image in turn depends essentially on particular characteristics and more generally on the quality of the product. It is on the latter, ultimately, that the product's reputation is based... For consumers, the link between the reputation of the producers and the quality of the products also depends on [their] being assured that products sold under the designation are authentic" (emphasis added). (Ravil SARLv Bellon Import [2003], para 49; see also Kingdom of Belgium v Kingdom of Spain [2000], paras 54-56).

${ }^{9}$ The Regulation began by noting in its Recitals that 'in recent years that consumers are tending to attach greater importance to the quality of foodstuffs rather than to quantity... [and] this quest for specific products generates a growing demand for agricultural products or foodstuffs with an identifiable geographical origin. [Therefore] in view of the wide variety of products marketed and of the abundance of information concerning them provided, consumers must, in order to be able to make the best choice, be given clear and succinct information regarding the origin of the product'.

10 "Two clear trends may be identified in European food production and consumption in recent years. First, one may note a shift of demand for agricultural products and foodstuffs bearing a geographical identification and reflecting traditional methods of production, the use of local raw materials and respect for the local environment ... Secondly, there has been a shift in the demand for agricultural products that have been awarded a designated quality label in the form of [GIs]" (Skuras \& Dimara, 2004, p. 801; see also Van Ittersum, Meulenberg, Van Trijp \& Candel, 2007; Verbeke, Pieniak, Guerrero \& Hersleth, 2012; Teuber, 2011b). 
${ }^{11}$ See respectively: (i) Council Regulation (EC) No. 479/2008 of 29 April 2008 on the common organisation of the market in wine, amending Regulations (EC) No. 1493/1999, (EC) No. 1782/2003, (EC) No. 1290/2005, (EC) No. 3/2008 and repealing Regulations (EEC) No. 2392/86 and (EC) No. 1493/1999; (ii) Commission Regulation 753/2002 of 29 April 2002 laying down certain rules for applying Council Regulation 1493/99 as regards the description, designation and protection of certain wine-sector products; (iii) Regulation 110/2008 of the European Parliament and of the Council of 15 January 2008 on the definition, description, presentation, labeling and the protection of geographical indications of spirit drinks deals with the use of geographical names for spirits; and (iv) Regulation (EU) No. 1151/2012 of the European Parliament and of the Council of 21 November 2012 on Quality Schemes for Agricultural Products and Foodstuffs.

${ }^{12}$ From an enforcement perspective, successful applicants have clearly defined rights and entitlements; publication in the register gives notice of the exclusive rights being claimed; the product specification with conditions for use are available for public inspection; and national/regional protection forms the basis for international protection (WIPO, 2001, paras 32-34; Serra, 2007).

${ }^{13}$ For these searchable databases, see respectively (1) http://ec.europa.eu/agriculture/quality/door/list.html; (2) http://ec.europa.eu/agriculture/markets/wine/e-bacchus/ and (3) http://ec.europa.eu/agriculture/spirits/index.cfm (Accessed on 10 Apr 2014).

${ }^{14}$ As per Advocate General Saggio in Kingdom of Belgium v. Kingdom of Spain ([2000], para 3; see also Réviron \& Chappuis, 2011, p. 46).

${ }^{15}$ Additional details are contained in the implementing rules. New rules are presently being drafted but a previous iteration can be found in Commission Regulation 1898/2006 of 14 December 2006 laying down detailed rules on implementation of Council Regulation 510/2006 on the protection of geographical indications and designations of origin for agricultural products and foodstuffs.

${ }^{16}$ As per Art 57 of Regulation 1151/2012, in the process of reaching its conclusion the Commission is advised by a standing Committee on Quality. See http://ec.europa.eu/agriculture/committees/quality en.htm (Accessed on 10 Apr 2014).

${ }^{17}$ The logos are available at: http://ec.europa.eu/agriculture/quality/schemes/logos/index en.htm (Accessed on 10 Apr 2014). Initially both logos used the same colour combination but a change (red for PDOs, blue for PGIs) was introduced via Commission Regulation (EC) No 628/2008 of 2 July 2008. The official reason given in the recitals is that this will enable consumers to more easily distinguish between PDOs and PGIs. However PDOs have historically been considered more prestigious and therefore valuable from a marketing perspective. There was also pressure from producers to clearly distinguish them from PGIs.

${ }^{18}$ Dossier No. UK/PDO/0017/0277. It can be accessed at: http://ec.europa.eu/agriculture/quality/door/list.html (Accessed on 10 Apr 2014).

${ }^{19}$ Dossier No. IT/PDO/0117/0067. It can be accessed at: http://ec.europa.eu/agriculture/quality/door/list.html (Accessed on 10 Apr 2014).

${ }^{20}$ Respectively, Dossier Nos. IT/PDO/0017/1565 and IT/PGI/0005/0430. They can be accessed at: http://ec.europa.eu/agriculture/quality/door/list.html (Accessed on $10 \mathrm{Apr} 2014$ ).

${ }^{21}$ Amendment is possible under Art 53 of Regulation 1151/2012. Further details concerning amendment procedure are found in Art 6 of Commission Delegated Regulation (EU) No 664/2014 of 18 December 2013 and Art 10 of Commission Implementing Regulation (EU) No 668/2014 of 13 June 2014.

${ }^{22}$ See respectively http://www.origin-gi.com/index.php/en/ and http://www.intracen.org/itc/market-infotools/geographical-indications/ (Accessed on $10 \mathrm{Apr} 2014$ ).

${ }^{23}$ See for e.g.: http://www.cirad.fr/en/research-operations/research-results/2006/geographical-indications-inemerging-countries (Accessed on 10 Apr 2014).

${ }^{24}$ See respectively: http://www.origin-food.org/ (Accessed on 10 Apr 2014). 